\title{
Vaginal isolation of beta-haemolytic Streptococcus from bitches with and without neonatal deaths in the litters
}

\author{
AE Guerrero $^{1,2}$ | MC Stornelli ${ }^{1}$ | SB Jurado ${ }^{3}$ | G Giacoboni ${ }^{2}$ | GH Sguazza ${ }^{4}$ | \\ RL de la Sota $^{1}$ | MA Stornelli ${ }^{1}$
}

${ }^{1}$ Cátedra y Servicio de Reproducción Animal, La Plata, Argentina

${ }^{2}$ Cátedra de Microbiología, La Plata, Argentina

${ }^{3}$ Servicio Central de Microscopía Electrónica, La Plata, Argentina

${ }^{4}$ Laboratorio de Virología, Facultad de Ciencias Veterinarias, Universidad Nacional de La Plata, La Plata, Argentina

\section{Correspondence}

Maria A. Stornelli, Cátedra y Servicio de Reproducción Animal, La Plata, Argentina.

Email: astornel@fcv.unlp.edu.ar

Funding information

UNLP. SENESCYT., Grant/Award Number: $11-230$

\section{Contents}

The aim of the study was to identify beta-haemolytic streptococci in the vagina of bitches who had delivered healthy litters and bitches who had delivered litters in which neonatal deaths occurred. Fifty-one bitches divided into two groups were used. Group 1 (G1) included 28 bitches that had delivered healthy litters and group 2 (G2) included 23 bitches that had delivered puppies who died in the neonatal period. Two vaginal samples were taken, one in proestrus and the other at the end of gestation (EG). Beta-haemolytic Streptococcus (BS) was isolated from 16 bitches (57\%) in G1 and from 21 bitches (91\%) in G2. The bacteriological cultures, serological tests (Streptex ${ }^{\circledR}$ ) and PCR assay allowed identification of Streptococcus canis and Streptococcus dysgalactiae in G1 and G2. Ultramicroscopic studies allowed the observation of M Protein and capsules in strains of S. dysgalactiae and S. canis in G1 and G2. The S. canis strains isolated from G2 showed thicker capsules than $S$. canis strains isolated from G1 (234 \pm 24.2 vs $151.23 \pm 28.93 \mathrm{~nm} ; p<.001$.). No differences were observed in capsule thickness between strains of $S$. dysgalactiae isolated from G1 and G2 (210 \pm 13.54 vs $211.66 \pm 19.67 \mathrm{~nm} ; p>$.70). All strains of beta-haemolytic Streptococcus isolated were penicillin sensitive. Penicillin was administered from EG to 5 days post-partum in 10 G2 females with isolation of BS (G2A). Saline solution was administered in eleven G2 females with isolation of BS (G2B). Ninety per cent of the puppies survived in G2A and $25 \%$ survived in $\mathrm{G} 2 \mathrm{~B}$. Our results suggest BS is involved in canine neonatal deaths.

\section{1 | INTRODUCTION}

Pup mortality, both during parturition and in the neonatal period, is a common and big problem in kennels, although poorly documented in the veterinary literature (Gill, 2001; Münnich, 2008; Tønnessen, Borge, Nødtvedt, \& Indrebø, 2012). Losses of puppies may occur in utero, during expulsion, after birth, in the first weeks of life and after weaning. The rate of perinatal death (stillborn puppies and neonates) is highly variable but highest during parturition, immediately after birth and in the first days of life. All together morbidity and mortality range from 5 to 35\% (Mosier, 1981; Münnich, 2008; Poffenbarger, Chandler, Ralston, \& Olson, 1990; Veronesi, Panzani, Faustini, \& Rota, 2009). Pup mortality has been attributed to a wide variety of causes including dystocia, congenital defects, low birth weight, infectious diseases, trauma and fading puppy syndrome (Gill, 2001; Mila et al., 2017). The principal cause of pup death was attributed to maternal factors and mothering failure (trauma, excessive licking, lactational failure and cannibalism; Andersen, 1957; Gill, 2001). Infectious diseases are the second most important cause of mortality and account for a large proportion of newborn losses (Münnich, 2008). In this way, infection with bacteria, rather than viruses, is the most common cause of death in the first week of age (Münnich, 2008; Nielen, van der Gaag, Knol, \& Shukken, 1998). However, information on sources of infections in newborn dogs is still limited. The environment and mothers are suspected as sources of infection (vaginal discharge, milk, faeces, oropharynx, skin) for 
puppies (Davidson, 2003; Münnich \& Lübke-Becker, 2004), similar to the situation in humans (Münnich, 2008). When puppies are exposed to bacteria and their defence mechanisms are overwhelmed, severe illness and newborn losses occur (Münnich, 2008). Reports show that the bacteria most frequently involved in neonatal mortality in dogs are E. coli, staphylococci, streptococci, Klebsiella spp., Proteus mirabilis and Pseudomona aeruginosa (Bjurström, 1993; Davidson, 2003; Johnston, Kuztritz, \& Olson, 2001; Mosier, 1981; Münnich, 2008; Sager \& Remmers, 1990; Schäfer-Somi, Spergser, Breitenfellner, \& Aurich, 2003). Streptococcus canis is the specie most frequently identified from cases of septicemia in newborn puppies, but other species of beta-haemolytic streptococci, such as Streptococcus agalactiae, Streptococcus equi subsp. zooepidemicus or Streptococcus dysgalactiae subsp dysgalactiae have also been implicated (Greene, 2012; Vela et al., 2012).

In humans, S. agalactiae or Lancefield group B (GBS) has been identified as one of the most important causal agents of serious infections and neonatal sepsis (Schrag et al., 2000; Schuchat, 1998). Around $40 \%$ of all pregnant women present rectal and/or vaginal GBS colonization (Regan, Klebanoff, \& Nugent, 1991). Vertical transmission from mother to the neonate has been documented (Edwards et al., 2008; Winn, 2007). In humans, the culture-based method is recommended for screening GBS. The standard method for the diagnosis of GBS colonization consists of culturing combined vaginal and anal swabs in a selective medium (Schrag et al., 2000). The antibiotic prophylaxis intrapartum for those women who have positive cultures for rectovaginal GBS colonization reduce neonatal infection (Bergeron et al., 2000; Boyer \& Gotoff, 1986; Garland \& Fliegner, 1991; Muller, Oostvogel, Steegers, \& Dörr, 2006). Aqueous penicillin G is the drug of choice in women. Like in women, in bitches, beta-haemolytic streptococci vaginal colonization could produce vertical infection and neonatal disease. The aim of this work was to identify beta-haemolytic streptococci in the vagina of bitches who had delivered healthy litters and bitches who had delivered litters in which neonatal deaths occurred.

\section{2 | MATERIALS AND METHOD}

\section{1 | Animals}

Fifty-one clinically healthy, intact bitches were used in this study. Bitches were from 10 different breeds (English Bulldog, French Bulldog, German Shepherd, Dogo Argentino, Dogue de Bordeaux, Pug, Schnauzer, Bernese, Labrador Retriever, Great Dane), were aged between two and 6 years old and weighed between 7 and $40 \mathrm{~kg}$. All bitches were referred to the University Veterinary Teaching Hospital of La Plata, Argentina to identify the proper timing of mating or insemination at the onset of the heat. Only bitches that became pregnant were included in the study. Animal care and experimentation complied with the International Guiding Principles for Biomedical Research Involving Animals (National Research Council, 2012). The Graduate School and the Laboratory Animal Care and Use Committees of the Faculty of Veterinary Sciences at National University of La Plata approved this study.
Animals were divided into two groups, group 1 (G1) included 28 bitches that have delivered healthy litters and group 2 (G2) included 23 bitches that have delivered puppies who died in the neonatal period in the previous two or three parturitions.

\subsection{Samples}

\subsection{1 | Vaginal cytology}

Each bitch was observed for sexual behaviour and clinical signs of heat. Vaginal cytology samples were obtained at the onset of heat and every other day until the onset of diestrus. Vaginal cytology samples were obtained by introducing a sterile cotton-tipped swab into the vagina and gently rotating it against the floor and lateral walls of the vagina. The swab was gently rolled over a clean microscopic slide, and smears were air-dried and stained with a modified Wright's stain. Stained slides were examined at 100 and 400xto count parabasal, intermediate and superficial cells. According to the percentage and type of cells present in the slide, proestrus and diestrus were identified (Johnston et al., 2001).

\subsection{2 | Bacteriological samples}

Two vaginal samples were taken from each bitch, one in proestrus (PR; between three and 7 days after the beginning of heat; sample 1[S1]) and the other one at the end of gestation (EG; between 45 and 48 days after the first day of cytological diestrus; sample 2[S2]). Samples were taken from the cranial portion of the vagina using a sterile vaginal swab through a sterile vaginoscope. The swabs were immediately introduced into Stuart media and transported to the microbiology laboratory (Groppetti, Pecile, Barbero, \& Martino, 2012).

\section{3 | Sample processing}

\subsection{1 | Bacteriological study}

Clinical samples were surface plated on Columbia agar (Oxoid, Britania S.A, CABA, Argentina) with 5\% sheep blood, selective media for Enterobacteriaceae (MacConkey agar; Oxoid, Britania S.A, CABA, Argentina) and agar TKT (toxine, kristal-violet, tallium) for streptococci. Agar plates were incubated at $37^{\circ} \mathrm{C}$ aerobically for 24 or $48 \mathrm{hr}$. The result was negative if bacterial growth was not visible after $48 \mathrm{hr}$. In addition, cultural procedures on blood agar media were performed after a 2-day enrichment in fluid Thioglycollate medium (Becton Dickinson, Sparks, MD, USA) and Trypticase Soy broth (Becton Dickinson). Bacterial identification was carried out on all isolates using standard identification methods (Schäfer-Somi et al., 2003; Winn et al., 2006).

\subsection{2 | Identification of beta-haemolytic streptococci}

After incubation, blood agar plates were inspected for betahaemolytic colonies. The isolates were characterized by phenotype, 
based on Gram stain and cell morphology. For beta-haemolytic streptococci, biochemical characterization was achieved (fermentation of lactose, maltose, cellobiose, sorbitol, arabinose, mannitol and trealosa, Bile Aesculin hydrolysis test [TP 2-Aesculin Hydrolysis Test], arginine hydrolysis test and Vogues Proskauer test) and colonies were submitted to the CAMP (Christie, Atkins, Munch, Petersen) test (Winn et al., 2006). In addition, Lancefield serological group reaction was determined (Daly \& Seskin, 1988).

\subsubsection{Serological identification of streptococci}

The streptococci serological identification was performed according to Lancefield classification (Lancefield, 1933) using the Streptex ${ }^{\circledR}$ Grouping Kit according to instructions defined by the manufacturer (Streptex, Clipper Boulevard West, Crossways Dartford, Kent, DA2 6PT UK; Daly \& Seskin, 1988).

\subsection{4 | Identification of streptococci by PCR amplification methods}

The DNA was extracted from 10 colonies of S. canis or S. dysgalactiae grown in pure culture, suspended in $100 \mu$ of PCR water incubated at $100^{\circ} \mathrm{C}$ for $10 \mathrm{~min}$ in a thermoblock, to produce a thermal lysis of the cell wall, and cooled in ice for $3 \mathrm{~min}$. The supernatant, obtained by centrifugation at $4293 \mathrm{~g}$ for $5 \mathrm{~min}$, was used as a template for PCR

(Preziuso, Laus, Tejeda, Valente, \& Cuteri, 2010).

To identify S. canis, PCR was performed with primers: Camp-I: $5^{\prime}$ CAA TTA ACT AAT AAG GTA GAA CAG-3' and camp-II 5' - СТC TCT CAA AAC GGG TG-3' (Hassan, Khan, Abdulmawjood, \& Lämmler, 2003). To identify $S$. dysgalactiae, PCR was performed with primers: dyCF 5'-AAG GAA ATG GAA CAC GTT AGG G-3' and adyR 5'-TCC TAC CAT GAC ACT AAT GTG TC-3 (Kawata et al., 2004). The oligonucleotide primers were custom synthesized by Integrated DNA Technology (IDT, Coralville, IA, USA).

For DNA amplification, $12.5 \mu \mathrm{l}$ of 2x PCR MasterMix (Promega; Fitchburg, Wisconsin, United State), 10 pmoles of each primer, $2.5 \mu \mathrm{l}$ of DNA template and $8 \mu \mathrm{l}$ of nuclease free water were mixed. PCR was performed in a thermal cycler (Cycler, Bio-Rad) using the following parameters: one cycle at $95^{\circ} \mathrm{C}$ for $5 \mathrm{~min}, 30$ cycles at $94^{\circ} \mathrm{C}$ for $1 \mathrm{~min}$, $58^{\circ} \mathrm{C}$ for $1.5 \mathrm{~min}$ and $72^{\circ} \mathrm{C}$ for $1.5 \mathrm{~min}$, followed by one cycle at $72^{\circ} \mathrm{C}$ for 5 min.

The electrophoretic analysis was performed using $2 \%$ agarose gel (Biodynamics. CABA, Argentina) and stained with ethidium bromide, using a marker of $100 \mathrm{pb}$ (Promega; Fitchburg, Wisconsin, United State). In each run, water instead of DNA was used as negative control. DNA of $\operatorname{ATCC}^{\circledR} 43497^{\mathrm{TM}}$ (S. canis) and $\operatorname{ATCC}^{\circledR} 43078^{\mathrm{TM}}$ (S. dysgalactiae) was used as positive controls. The positivity consisted of a band corresponding to $238 \mathrm{bp}$ and $1508 \mathrm{bp}$, respectively.

\subsection{5 | Antibiotic sensitivity}

Antibiotic sensitivity for beta-haemolytic streptococci was carried out by the Kirby-Bauer method. Antimicrobials tested were penicillin
(10UI), vancomycin (30ug) and eritromycin (15ug; Britania S.A., CABA, Argentina) according to CLSI standards (CLSI, 2013; CLSI, 2016).

\subsection{6 | Therapeutic trial}

Twenty-one $\mathrm{G} 2$ bitches with isolation of beta-haemolytic Streptococcus were included in the therapeutic trial. $\mathrm{G} 2$ bitches were divided into two groups. In G2A ( $n=10$ ), benzathine Penicilin G (Penicilina G benzatínica ${ }^{\circledR}$; Veterquimica) $24.000 \mathrm{lU} / \mathrm{kg} / 48 \mathrm{hr}$ (Bonagura \& Tewdt, 2008) was administered from 50 days after the first day of cytological diestrus to five days post-partum. In G2B ( $n=11$ ), saline solution was administered from 50 days after the first day of cytological diestrus to 5 days post-partum.

\subsection{7 | Ultramicroscopic study}

When beta-haemolytic streptococci were isolated, to perform after species identification and to study the presence or absence of $\mathrm{M}$ protein and capsules, isolated colonies were observed using a transmission electron microscope (TEM). Colonies were suspended in sterile saline solution for direct observation using negative staining. In addition, after initial isolation, bacteria were transferred into a blood agar media and incubated for $24 \mathrm{hr}$ or $48 \mathrm{hr}$ at $37^{\circ} \mathrm{C}$ under aerobic conditions to obtain a sufficient number of bacterial colonies to process the sample for TEM. Then, colonies were processed to obtain ultrathin sections and were finally observed with TEM. To do negative staining, a bacterial suspension drop was put on a copper mesh (400 mesh) coated with collodion for $5 \mathrm{~min}$. After that, the excess was removed on a filter paper. Bacteria adhered to the mesh were negatively stained with phosphotungstic acid $2 \%$ for 40 s and then observed with TEM (JEM 1200 EX II; JEOL Ltd., Tokyo, Japan). To obtain ultrathin sections, colonies were fixed in 3\% glutaraldehyde in $0.1 \mathrm{M}$ phosphate buffer with $0.5 \%$ of alcian blue and post-fixed in $1 \%$ osmium tetroxide (OsO4). The samples were centrifuged; the pellets were dehydrated and then embedded in epoxy resin. Ultrathin serial sections (90 nm) were picked up on copper grids, counterstained with uranyl acetate and lead citrate and examined in a JEM 1200 EX II (JEOL, Japan) TEM microscope at $80 \mathrm{Kv}$.

The bacterial morphology and $M$ protein and capsule presence were studied. Capsule thickness was measured on micrographs taken during the electron microscopic observations. For each betahaemolytic Streptococcus strain, mean values were calculated from 10 to 15 Streptococcus cells per micrograph.

\subsection{Statistics analyses}

Data were analysed by ANOVA. The model used included the effect of group (bitches with history of delivering health puppies [G1]; bitches with history of delivering puppies that died in the neonatal period [G2]), stage of cycle that bacteriological sample was taken (proestrus [PR], end of gestation [EG]); and type of bacteria isolated (Staphylococcus spp. [STA], beta-haemolytic Streptococcus [BHS], E. coli, Proteus spp., non-fermenting Gram-negative bacilli [NFGNB], Enterococcus spp. 
TABLE 1 Percentage of bacteria isolated from vaginal samples obtained from Group 1 bitches

\begin{tabular}{|llc|}
\hline Bacteria & S1 $^{\mathrm{A}}$ & $\mathrm{S2}^{\mathrm{B}^{\mathrm{B}}}$ \\
\hline$\beta$-haemolytic Streptococcus & $57.1 \%$ & $35.7 \%$ \\
\hline Staphylococcus spp. & $42.8 \%$ & $46.28 \%$ \\
\hline Escherichia coli & $21.42 \%$ & $28.57 \%$ \\
\hline NFGNB & & $14.28 \%$ \\
\hline Enterococcus spp. & $14.28 \%$ & $3.6 \%$ \\
\hline Proteus spp. & $3.6 \%$ & $5.71 \%$ \\
\hline
\end{tabular}

$\mathrm{S}^{\mathrm{A}}$, proestrus [PR] sample; $\mathrm{S} 2^{\mathrm{B}}$, end of gestation [EG] sample; $\mathrm{NFGNB}^{\mathrm{C}}$, non-fermenting Gram-negative bacilli.

TAB LE 2 Percentage of bacteria isolated from vaginal samples obtained from Group 2 bitches

\begin{tabular}{|llr|}
\hline Bacteria & $\mathrm{S1}^{\mathrm{A}}$ & $\mathrm{S2}^{\mathrm{B}}$ \\
\hline$\beta$-haemolytic Streptococcus & $78.3 \%$ & $69.6 \%$ \\
\hline Staphylococcus spp. & $43.47 \%$ & $34.8 \%$ \\
\hline Escherichia. Coli & $21.7 \%$ & $21.7 \%$ \\
\hline NFGNB $^{\mathrm{C}}$ & $13.1 \%$ & $4.3 \%$ \\
\hline Enterococcus spp. & $13.1 \%$ & $13.1 \%$ \\
\hline Proteus spp. & $8.7 \%$ & $8.7 \%$ \\
\hline
\end{tabular}

$S 1^{A}$, proestrus [PR] sample; $S 2^{B}$, end of gestation [EG] sample; $\mathrm{NFGNB}^{\mathrm{C}}$, non-fermenting Gram-negative bacilli.

[ENTB]). The type of bacteria isolated was analysed by categorical data analysis using the GENMODE procedure of SAS (2003) with binomial distribution and logit link function. The Streptococcus capsule thickness was analysed by general linear models using the MIXED procedure of SAS ${ }^{2}$ (2003). Data are shown as least squares means \pm standard error $(\mathrm{LSM} \pm S E)$, and statistical significance was set at $p<.05$.

\section{3 | RESULTS}

In vaginal samples, Staphylococcus spp., beta-haemolytic Streptococcus, E. coli, Proteus spp., NFGNB and Enterococcus spp. were found (Table 1 and Table 2). Vaginal samples showed bacterial growth of two, three or four genera. No difference was observed between groups in bacterial genera isolation. The biochemical, physiological and serological tests used for typifying beta-haemolytic streptococci allowed identification of Streptococcus dysgalactiae and Streptococcus canis in vaginal samples. The PCR reaction confirmed the species of streptococcus typified by biochemical and serological methods.

In G1 and G2, beta-haemolytic Streptococcus isolated was biochemically characterized as S. canis and S.dysgalactiae. In G1,
Lancefield serological group and PCR reaction identified nine strains as $\mathrm{G}$ Lancefield group (S. canis) and seven as C Lancefield group (S. dysgalactiae). In G2, Lancefield serological group and PCR reaction identified 16 strains as $\mathrm{G}$ Lancefield group (S. canis) and five as C Lancefield group (S. dysgalactiae; Table 3).

The percentage of samples (S1 and S2) with beta-haemolytic Streptococcus in the vagina was higher in G2 compared with G1 (73.91 vs $46.43 \pm 0.43 \%$; $p$ <.05). No differences were observed between S1 and S2 in any group. No differences were observed between G1 and $\mathrm{G} 2$ or S1 and S2 in other isolated bacterial genera.

The beta-haemolytic streptococci isolated showed no bacterial resistance for any of the antibiotics used in the antibiotic sensitivity test.

In the ultramicroscopic study, capsules (Figure 1) and M protein (Figure 2) were observed in S. canis and S. dysgalactiae. Capsules were observed by direct observation using negative staining in 21 of the 22 strains of S. canis and S. dysgalactiae studied (Table 4). Seventeen strains of S. canis and S. dysgalactiae were observed in ultrathin sections. M protein was observed in the 17 samples.

No differences were observed in capsule thickness between strains of S. canis and S. dysgalactiae $(218.95 \pm 21.56$ vs $210.71 \pm 10.39$ nm; $p>.62$ ). The $S$. canis strains isolated from G2 (S1 and S2) showed capsules thicker than $S$. canis strains isolated from G1 (234 \pm 24.2 vs $151.23 \pm 28.93 \mathrm{~nm} ; p<.001)$. No differences were observed in capsule thickness between strains of $S$. dysgalactiae isolated from G1 and $\mathrm{G} 2(210 \pm 13.54$ vs $211.66 \pm 19.67 \mathrm{~nm} ; p>.70)$.

No stillbirths were recorded in either G1 or G2. The therapeutic trial showed differences in neonatal survival in G2A compared with G2B. Fifty-seven puppies were born in G2A. The 10 bitches included in G2A delivered healthy litters and $90 \%(51 / 57)$ of puppies survived. Six puppies (10\%) died in the neonatal period. Sixty-eight puppies were born in G2B. The 11 bitches included in G2B delivered healthy litters but only $25 \%(17 / 68)$ of puppies survived. Fifty-one puppies (75\%) died in the neonatal period.

\section{4 | DISCUSSION}

Vaginal microbiota findings in our work were similar to the findings reported by other authors (Carneiro, Toniollo, \& Schocken-Iturrino, 2005; Groppetti et al., 2012; Laurusevičius, Jūratè, \& Henrikas, 2008; Watts, Wright, \& Whithear, 1996). Staphylococcus spp. were isolated in healthy bitches during proestrus and at the end of gestation in a lower percentage compared to other studies that reported percentages up to $76.19 \%$ in healthy bitches and up $71.42 \%$ in bitches with reproductive pathologies (Carneiro et al., 2005). In the same way, E. coli was found in this study in a lower percentage

\begin{tabular}{lclr} 
Bitches & $\boldsymbol{\beta}$-hemolytic Streptococcus & \multicolumn{1}{l}{ S. canis } & \multicolumn{1}{c}{ S. dysgalactiae } \\
\hline $\mathrm{G} 1^{\mathrm{A}}(n=28)$ & $57.14 \%(n=16)$ & $32.14 \%(n=9)$ & $25.00 \%(n=7)$ \\
$\mathrm{G} 2^{\mathrm{B}}(n=23)$ & $91.3 \%(n=21)$ & $69.56 \%(n=16)$ & $21.73 \% 7(n=5)$ \\
\hline
\end{tabular}

TABLE 3 Percentage of bitches with $\beta$-haemolytic streptococci (Streptococcus canis or Streptococcus dysgalactiae) isolated from vaginal samples from bitches

A Group 1, bitches with healthy litters; ${ }^{\mathrm{B}}$ Group 2, bitches with newborn deaths in the litters. 

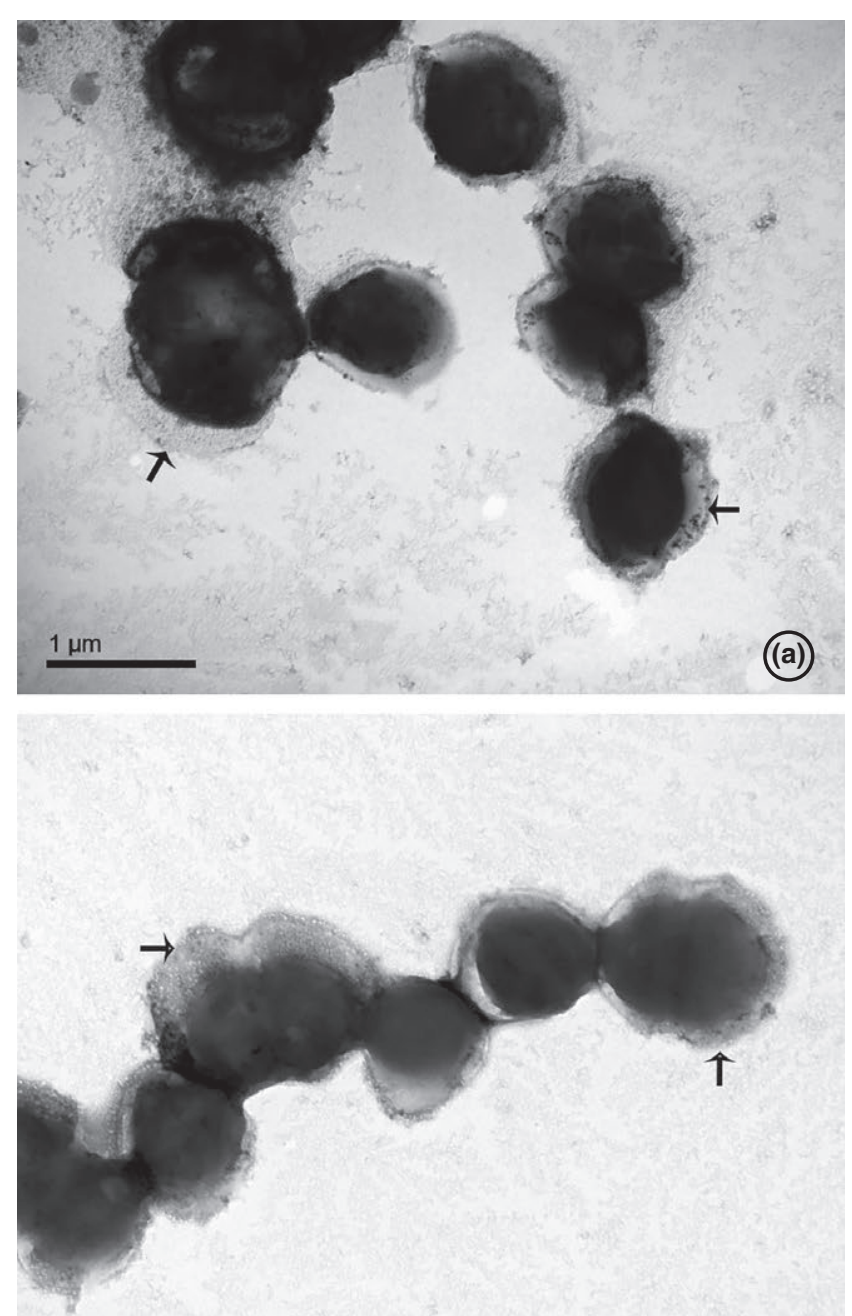

$1 \mu \mathrm{m}$

(bi)

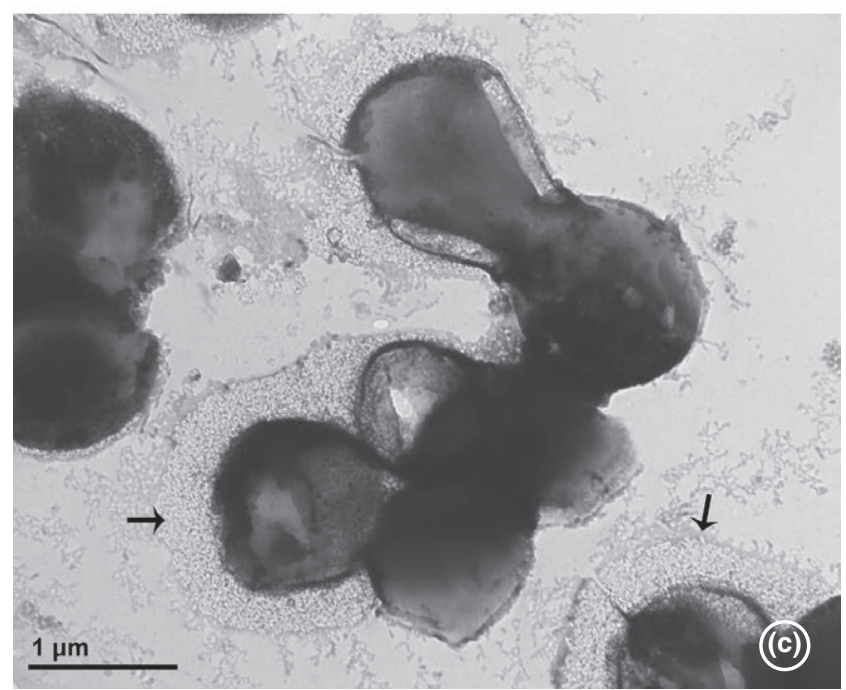

FIGURE 1 Electron micrograph of Streptococcus canis and Streptococcus dysgalactiae (negative staining). Arrows show capsule. Bar, 0,2 $\mu \mathrm{m}$. A: S. dysgalactiae. B: S. canis (G1). C: S. canis (G2)

compared with another study in healthy bitches (66.66\%) and in bitches with reproductive pathologies (71.42\%; Carneiro et al., 2005). On the other hand, E. coli was found by Groppetti et al.
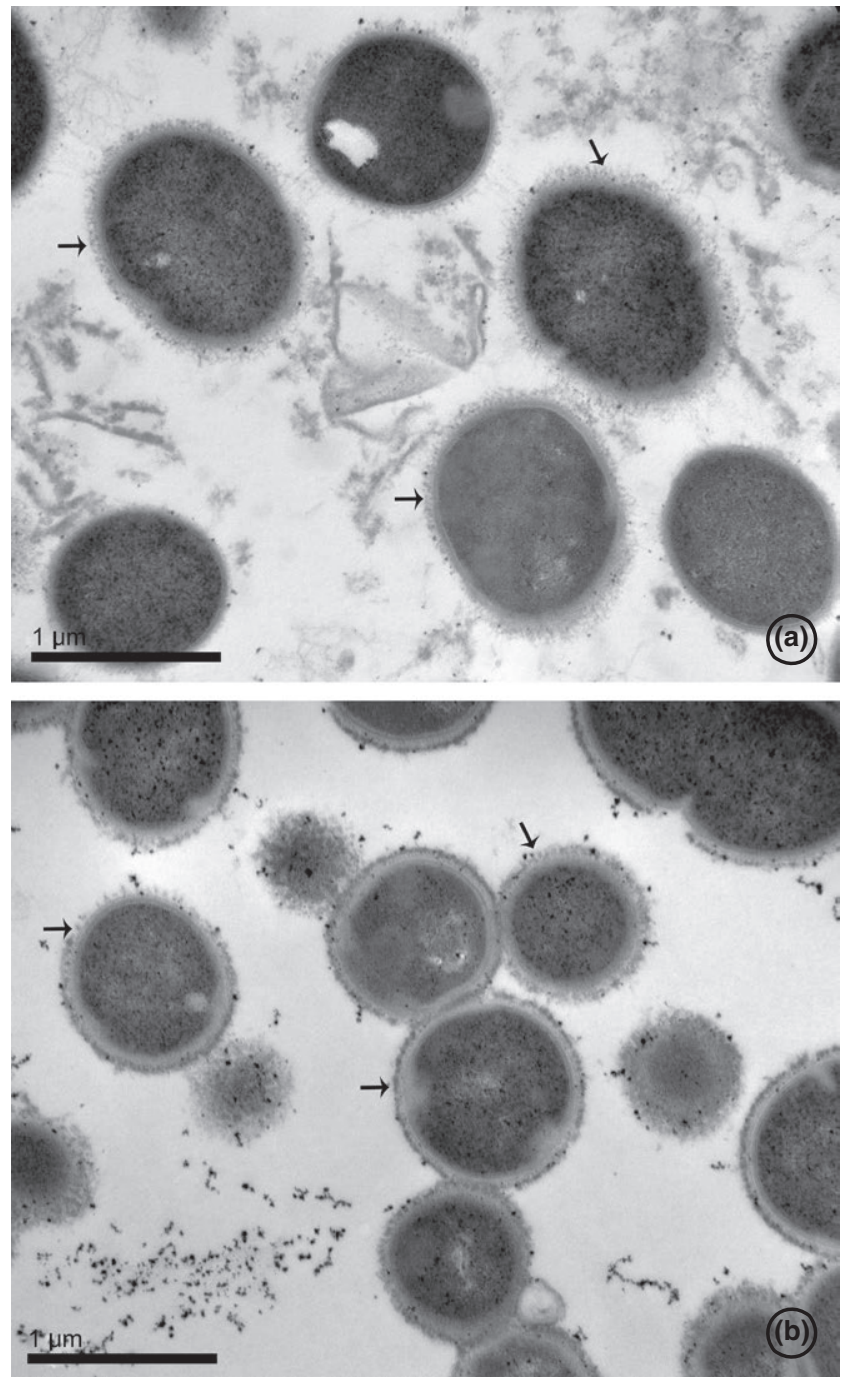

FIGURE 2 Electron micrographs of Streptococcus dysgalactiae and Streptococcus canis (ultrathin sections). Arrows show M protein. Bar, $0,2 \mu \mathrm{m}$. A: S. dysgalactiae. B: $S$

(2012) during proestrus in lower percentages than in the current study (2.9\%). In the present study, beta-haemolytic Streptococcus was the bacteria more frequently isolated. Our finding agrees with data reported by Allen and Dagnall, who found beta-haemolytic Streptococcus as one of the more frequently isolated bacteria from healthy pregnant or nonpregnant bitches, and infertile bitches with vaginal discharge (Allen \& Dagnall, 1982). In our study, betahaemolytic Streptococcus was the bacteria most frequently isolated in $\mathrm{G} 2$ in proestrus and at the end of gestation. The percentage of beta-haemolytic Streptococcus observed in the present study in S1 in G1 and G2 were higher from those reported by Groppetti et al. (2012), who founded a smaller percentage (20.6\%) in healthy bitches during proestrus.

Streptococcus canis was the most frequently beta-haemolytic Streptococcus isolated in our study. These bacteria were previously isolated by other researches from the vagina of bitches in heat (Allen \& Dagnall, 1982; Watts et al., 1996); and Streptococcus dysgalactiae was previously isolated from the canine pharynx (Acke et al., 2015; 


\begin{tabular}{lccllll} 
Group & $I S^{\mathrm{A}} /$ S. canis & $\mathrm{BC}^{\mathrm{B}}$ & $\mathrm{WC}^{\mathrm{C}}$ & $\mathrm{IS}^{\mathrm{D}} /$ S. dysgalactiae & $\mathrm{BC}^{\mathrm{B}}$ & $\mathrm{WC}^{\mathrm{C}}$ \\
$\mathrm{G}^{\mathrm{E}}$ & 4 & 3 & 1 & 3 & 3 & 0 \\
$\mathrm{G}^{\mathrm{F}}$ & 11 & 11 & 0 & 4 & 4 & 0 \\
\hline
\end{tabular}

TABLE 4 Capsule observation using negative stainin in strains of Streptococcus canis and Streptococcus dysgalactiae isolated from vaginal samples from bitches

$I S^{A} / S$. canis, number of strains isolated of $S$. canis; $B C^{B}$, number of strains with bacterial capsule; $\mathrm{WC}^{\mathrm{C}}$, number of strains without bacterial capsule; $I \mathrm{~S}^{\mathrm{D}} / \mathrm{S}$. dysgalactiae, number of strains isolated of $S$. dysgalactiae; $\mathrm{G}^{\mathrm{E}}$, bitches with healthy litters; $\mathrm{G}^{\mathrm{F}}$, bitches with newborn deaths in the litters.

Schrieber, Towers, Muscatello, \& Speare, 2014). However, according to our knowledge, it has not been isolated from the canine reproductive tract.

The S. canis and S. dysgalactiae isolation in the bitch vagina in G1 and G2 showed that the microorganisms were present in both groups of bitches. The $\mathrm{G} 2$ bitches at the end of gestation had a higher percentage (69.6\%) of beta-haemolytic Streptococcus isolated compared with the percentage reported in women (40\%) in the last third of gestation (de-Paris et al., 2011; Winn, 2007). On the other hand, the percentage of beta-haemolytic Streptococcus found in G2 bitches was twice that found in G1. These findings could support the notion of bacteria transmission to the neonate during the parturition similar to findings in human (de-Paris et al., 2011; Schuchat, 1998; Winn, 2007). In humans, vertical transmission and neonatal illness was reported in 75 per cent of the newborns from mothers with vaginal colonization of betahaemolytic Streptococcus (de-Paris et al., 2011; Winn, 2007). This process could also happen in the dog since beta-haemolytic Streptococcus was isolated in the vagina in G1 bitches at the end of gestation.

No difference was observed between groups in the bacterial genera isolation except in beta-haemolytic Streptococcus. These findings suggest Staphylococcus spp., E. coli, Proteus spp., non-fermenting Gram-negative bacilli [NFGNB] and Enterococcus spp. are not involved in neonatal deaths in the bitches included in this work.

In the ultramicroscopic study, we observed M protein and capsule in S. canis y S. dysgalactiae. The M protein and capsule observed in the beta-haemolytic Streptococcus studied in this work could be involved in the pathogenicity of the bacteria. Ultramicroscopic studies showed the presence of $M$ protein in S. canis and S. dysgalactiae in ultrathin sections. Our findings agree with previous reports by other researchers (Brandt \& Spellerberg, 2009; De Winter, Low, \& Prescott, 1999; Vasi, Frykberg, Carlsson, Lindberg, \& Guss, 2000). The capsule was described in S. dysgalactiae (Brandt \& Spellerberg, 2009). However, according to our knowledge, there are no previous reports about capsule description in S. canis. In the same way, the capsule was observed in S. equi and S. pyogenes using negative staining, the same staining used in the current study (Bustos, Muñoz, \& Guida, 2015; Cleary \& Cheng, 2006; Fazio \& Fischetti, 2004). Vanrobaeys et al. reported that the thickness of the S. gallolyticus capsule is related to the virulence of the strain studied. The most virulent strains have thicker capsules (Vanrobaeys, De Herdt, Charlier, Ducatelle, \& Haesebrouck, 1999). The S. canis strains isolated in G2 showed thicker capsules than strains isolated in G1. This finding could be related to the pathogenicity of the strain isolated in $\mathrm{G} 2$ and the neonatal death observed in puppies delivered by $\mathrm{G} 2$ bitches. In contrast, no differences were observed in thickness of the capsules in S. dysgalactiae strains isolated from G1 and G2. Several pathogenicity factors of $S$. dysgalactiae are known (M protein, streptolysin O, streptolysin S, streptokinase, streptodornase [DNasa], pyrogenic exotoxin G and hyaluronidasa; Brandt \& Spellerberg, 2009; Timoney, 2010). It is likely that in the current study, the strains of the groups $\mathrm{G} 1$ and $\mathrm{G} 2$ of $S$. dysgalactiae differ not in the thickness of the capsule but in other factors of virulence not studied in this work.

Streptococcus canis and S. dysgalactiae strains isolated from vaginas in G1 and G2 showed penicillin and vancomicin sensitivity agreeing with S. canis strains isolated from bitch vaginas and cow milk by Hassan, Akineden, and Usleber (2005), and Pinho et al. (2013) and S. dysgalactiae strains isolated from the human pharynx (Rantala, 2014; Woo, Fung, Lau, Wong, \& Yuen, 2001). In contrast, Lysková, Vydržalová, Královcová, and Mazurová (2007) found some S. canis strains with vancomicin resistance isolated to external ears canal, vaginal mucosa, pharynx and oral cavity, conjunctivae, skin and the rectum in dogs. Gianneechini et al. (2014), found some S. dysgalctiae strains with erythromycin resistance isolated from dairy cows with subclinical mastitis. Woo et al. (2001) isolated erythromycin resistance S. dysgalactiae strains from human.

The current study showed that penicillin administration before and after parturition reduced neonatal death in G2. These findings agree with the reduction of neonatal infection and death in humans by penicillin administration during the parturition in women with vaginal colonization of beta-haemolytic Streptococcus (Verani, McGee, Stephanie, \& Schrag, 2010).

Our results suggest beta-haemolytic Streptococcus could cause neonatal deaths when bitches have vaginal colonization. The antibiotic administration in pregnant bitches that a history of neonatal deaths and beta-haemolytic streptococci vaginal colonization could avoid neonatal deaths. The use of antibiotics in all bitches to reduce the incidence of neonatal death is not recommended because of antibiotic resistance. But, in bitches that have delivered puppies who died in the neonatal period, in previous parturitions, in which beta-haemolytic Streptococcus have been isolated, the administration of penicillin could improve neonatal survival and reduce neonatal deaths. Therefore, the bacteriological study of vaginal samples obtained from bitches with a history of delivering puppies that died in the neonatal period would be an important tool to selectively treat these bitches before parturition to reduce/minimize neonatal death. More studies are needed on this topic to clarify the proper use of antibiotics and the role of beta-haemolytic Streptococcus in the neonatal deaths when the bitch presents vaginal colonization. 


\section{CONFLICT OF INTEREST}

The authors have declared no conflict of interests.

\section{AUTHOR CONTRIBUTIONS}

Guerrero AE helped to design, conduct the experiment, and process the samples, analysed data and drafted manuscript. Stornelli MC, Jurado SB, Giacoboni G and Sguazza GH, helped to conduct the experiment and process the samples. Stornelli MA and de la Sota RL helped to design and conduct the experiment and critically revised the manuscript.

\section{ORCID}

MA Stornelli iD http://orcid.org/0000-0001-7285-1814

\section{REFERENCES}

Acke, E., Midwinter, A. C., Lawrence, K., Gordon, S. J., Moore, S., Rasiah, I., ... Waller, A. (2015). Prevalence of Streptococcus dysgalactiae subsp. equisimilis and S. equi subsp. zooepidemicus in a sample of healthy dogs, cats and horses. New Zealand Veterinary Journal, 63(5), 265-271. https://doi.org/10.1080/00480169.2015.1016133

Allen, W. E., \& Dagnall, G. J. R. (1982). Some observations on the aerobic bacterial flora of the genital tract of the dog and bitch. Journal of Small Animal Practice, 23, 325-335. https://doi.org/10.1111/j.1748-5827.1982. tb01674.x

Andersen, A. C. (1957). Puppy production to the weaning age. Journal of the American Veterinary Medical Association, 130, 151-158.

Bergeron, M. G., Danbing, K. E., Menard, C., François, F. J., Gagnon, M., Bernier, M., ... Fraser, W. D. (2000). Rapid detection of group B streptococci in pregnant women at delivery. New England Journal of Medicine, 343, 175-179. https://doi.org/10.1056/ NEJM200007203430303

Bjurström, L. (1993). Aerobic bacteria occurring in the vagina of bitches with reproductive disorders. Acta Veterinaria Scandinavica, 34(1), 29-34.

Bonagura, J. D., \& Tewdt, D. C. (2008). Kirk's current veterinary therapy (14thed). St. Louis, Missouri: ELSEVIER Saunders.

Boyer, K. M., \& Gotoff, S. P. (1986). Prevention of early-onset neonatal group B streptococcal disease with selective intrapartum chemoprophylaxis. New England Journal of Medicine, 314, 1665-1669. https://doi. org/10.1056/NEJM198606263142603

Brandt, C. M., \& Spellerberg, B. (2009). Human infections due to Streptococcus dysgalactiae subspecies equisimilis. Clinical Infectious Disease, 49(5), 766-772. https://doi.org/10.1086/605085

Bustos, C. P., Muñoz, A. J., \& Guida, N. (2015). Expresión de la cápsula en aislamientos de Streptococcus equi subsp. Equi. Revista Argentina de Microbiología, 47(4),380-381. https://doi.org/10.1016/j.ram.2015.07.005

Carneiro, A., Toniollo, G., \& Schocken-Iturrino, R. (2005). Avaliação microbiológica da flora vaginal e do corpo uterino de cadelas (Canis familiaris) submetidas a ovariossalpingohisterectomia. Ars veterinaria, jaboticaba, 21(3), 361-367.

Cleary, P., \& Cheng, Q. (2006). Medically important $\beta$-hemolytic Streptococci. In M. Dworkinm, S. Falkow, E. Rosenberg, K.-H. Schleifer, \& E. Stackebrandt (Eds.), The prokaryotes, 3rd ed. USA: Springer, New York.

Clinical Laboratory Standards Institute (CLSI), (2013): M100-S3 performance standards for antimicrobial susceptibility testing. Twenty-Third Informational Supplement Wayne, PA: Clinical Laboratory Standards Institute.
Clinical Laboratory Standards Institute (CLSI), (2016): M100-S 26th edition performance standards for antimicrobial susceptibility testing. TwentyFourth Informational Supplement Wayne, PA: Clinical Laboratory Standards Institute.

Council for International Organization of Medical Sciences and the international council for laboratory animal science (CIOMS-ICLAS), 2012: International Guiding Principles for Biomedical Research Involving Animals.

Daly, J. A., \& Seskin, K. C. (1988). Evaluation of rapid, commercial latex techniques for serogrouping beta-hemolytic streptococci. Journal of Clinical Microbiology, 26(11), 2429-2431.

Davidson, A. P. (2003). Approaches to reducing neonatal mortality in dogs. In P. W. Concannon, G. England, J. Verstegen, \& C. LindeForsberg (Eds.), Recent advances in small animal reproduction. Ithaca, NY: International Veterinary Information Service. (http://www.ivis. org).

De Winter, L. M., Low, D. E., \& Prescott, J. F. (1999). Virulence of Streptococcus canis from canine streptococcal toxic shock syndrome and necrotizing fasciitis. Veterinary Microbiology, 70(1-2), 95-110. https://doi.org/10.1016/S0378-1135(99)00128-5

Edwards, R. K., Novak-Weekley, S. M., Koty, P. P., Davis, T., Leeds, L. J., \& Jordan, J. A. (2008). Rapid Group B streptococci screening using a realtime polymerase chain reaction assay. Obstetrics \& Gynecology, 111, 1335-1341. https://doi.org/10.1097/AOG.0b013e31817710ee

Fazio, M., \& Fischetti, V. A. (2004). Streptococcus pyogenes -transmission electron micrograph. With permission. New York, NY: The Laboratory of Bacterial Pathogenesis and Immunology, Rockefeller University.

Garland, S. M., \& Fliegner, J. R. (1991). Group B Streptococcus (GBS) and neonatal infections: The case for intrapartum chemoprophylaxis. The Australian \& New Zealand journal of obstetrics \& gynaecology, 31, 119122. https://doi.org/10.1111/j.1479-828X.1991.tb01797.x

Gianneechini, R., Concha, C., Delucci, I., Gil, J., Salvarrey, L., \& Rivero, R. (2014). Bovine mastitis, distribution of pathogens and antimicrobial resistance in the Southern Dairy Basin of Uruguay. Veterinaria, 50(196), 4-32.

Gill, M. A. (2001). Perinatal and late neonatal mortality in the dog. (Doctoral thesis). University of Sydney, Sydney, Australia.

Greene, C. E. (2012). Infectious diseases of the dog and cat, 4th ed. St. Louis, Missouri: ELSEVIER Saunders.

Groppetti, D., Pecile, A., Barbero, C., \& Martino, P. A. (2012). Vaginal bacterial flora and cytology in proestrous bitches: Role on fertility. Theriogenology, 77(8), 1549-1556. https://doi.org/10.1016/j. theriogenology.2011.11.022

Hassan, A. A., Akineden, O., \& Usleber, E. (2005). Identification of Streptococcus canis isolated from milk of dairy cows with subclinical mastitis. Journal of Clinical Microbiology., 43(3), 1234-1238. https://doi. org/10.1128/JCM.43.3.1234-1238.2005

Hassan, A. A., Khan, I. U., Abdulmawjood, A., \& Lämmler, C. (2003). Development of PCR assays for detection of Streptococcus canis. FEMS Microbiology Letters, 219(2), 209-214.

Johnston, D. J., Kuztritz, M. V. R., \& Olson, P. (2001). Canine and feline theriogenology. Philadelphia: WB Saunders.

Kawata, K., Anzai, T., Senna, K., Kikuchi, N., Ezawa, A., \& Takahashi, T. (2004). Simple and rapid PCR method for identification of streptococcal species relevant to animal infections based on 23S rDNA sequence. FEMS Microbiology Letters, 237(1), 57-64. https://doi. org/10.1111/j.1574-6968.2004.tb09678.x

Lancefield, R. C. (1933). A serological differentiation of human and other groups of streptococci. Journal of Experimental Medicine, 59, 571-595. https://doi.org/10.1084/jem.57.4.571

Laurusevičius, S. A., Jūratè, Š., \& Henrikas, Ž. (2008). Correlation between different sexual cycle stages and vaginal bacterial flora in bitches of different breeds. Lithuanian Veterinary Academy, Tilžès st., 18, LT-47181. 
Lysková, P., Vydržalová, M., Královcová, D., \& Mazurová, J. (2007) Prevalence and Characteristics of Streptococcus canis Strains Isolated from Dogs and Cats. Pardubice Czech Republic. Acta Veterinaria Brno, 76, 619-625. https://doi.org/10.2754/avb200776040619

Mila, H., Grellet, A., Delebarrea, M., Marianic, C., Feugierc, A., \& ChastantMaillarda, S. (2017). Monitoring of the newborn dog and prediction of neonatal mortality. Preventive Veterinary Medicine, 143, 11-20. https:// doi.org/10.1016/j.prevetmed.2017.05.005

Mosier, J. E. (1981). Canine pediatrics - The neonate. Proceedings of the 48th AAHA Annual. Meeting, 339-347.

Muller, A. E., Oostvogel, P. M., Steegers, E. A. P., \& Dörr, P. J. (2006). Morbidity related to maternal group B streptococcal infections. Acta Obstetricia et Gynecologica Scandinavica., 85, 1027-1037. https://doi. org/10.1080/00016340600780508

Münnich, A. (2008). The pathological newborn in small animals: The neonate is not a small adult. Veterinary Research Communications, 32(1), 81-85. https://doi.org/10.1007/s11259-008-9096-0

Münnich, A., \& Lübke-Becker, A. (2004). Escherichia coli infections in newborn puppies-clinical and epidemiological investigations. Theriogenology, 62(34), 562-575. https://doi.org/10.1016/j.theriogenology.2003.11.012

Nielen, A. L., van der Gaag, I., Knol, B. W., \& Shukken, Y. H. (1998). Investigation of mortality and pathological changes in 14-month birth cohort of boxer puppies. The Veterinary Record, 142, 602-606. https:// doi.org/10.1136/vr.142.22.602

de-Paris, F., Machado, A. B., Gheno, T. C., Ascoli, B. M., Oliveira, K. R., \& Barth, A. L. (2011). Group B Streptococcus detection: Comparison of PCR assay and culture as a screening method for pregnant women. Brazilian Journal of Infectious Disease, 15(4), 323-327. https://doi. org/10.1016/S1413-8670(11)70199-4

Pinho, M. D., Matos, S. C., Pomba, C., Lübke-Becker, A., Wieler, L. H., Preziuso, S., ... Ramirez, M. (2013). Multilocus sequence analysis of Streptococcus canis confirms the zoonotic origin of human infections and reveals genetic exchange with Streptococcus dysgalactiae subsp. equisimilis. Journal of Clinical Microbiology., 51(4), 1099-1109. https:// doi.org/10.1128/JCM.02912-12

Poffenbarger, E. M., Chandler, M. L., Ralston, S. L., \& Olson, P. M. (1990). Canine neonatology. Part 1: Physiologic differences between puppies and adults. Compendium on Continuing Education for the Practicing Veterinarian., 12, 1601-1609.

Preziuso, S., Laus, F., Tejeda, A. R., Valente, C., \& Cuteri, V. (2010). Detection of Streptococcus dysgalactiae subsp. equisimilis in equine nasopharyngeal swabs by PCR. Journal of Veterinary Science, 11(1), 67-72. https:// doi.org/10.4142/jvs.2010.11.1.67

Rantala, S. (2014). Streptococcus dysgalactiae subsp. equisimilis bacteremia: An emerging infection. European Journal of Clinical Microbiology Infectious \& Disease, 33(8), 1303-1310. https://doi.org/10.1007/s10096-014-2092-0

Regan, J. A., Klebanoff, M. A., \& Nugent, R. P. (1991). The epidemiology of group $B$ streptococcal colonization in pregnancy. Vaginal Infections and Prematurity Study Group. Obstetrics \& Gynecology, 77, 604-610.

Sager, M., \& Remmers, C. (1990). Perinatal mortality in dogs. Clinical, bacteriological and pathological studies. [Article in German]. Tierarztliche Praxis, 18(4), 415-419.

SAS ${ }^{\circledR}$ (2003). SAS and STAT User's Guide, Release 9.1. Cary, NC: SAS Institute Inc.

Schäfer-Somi, S., Spergser, J., Breitenfellner, J., \& Aurich, J. E. (2003). Bacteriological status of canine milk and septicaemia in neonatal puppies-a retrospective study. Journal of Veterinary Medicine. B Infectious and Diseases Veterinary. Public Health, 50(7), 343-346.

Schrag, S. J., Zywicki, S., Farley, M. M., Reingold, A. L., Harrison, L. H., Lefkowitz, L. B., ... Schuchat, A. (2000). Group B streptococcal disease in the era of intrapartum antibiotic profilaxis. New England Journal of Medicine, 342, 15-20. https://doi. org/10.1056/NEJM200001063420103

Schrieber, L., Towers, R., Muscatello, G., \& Speare, R. (2014). Transmission of Streptococcus dysgalactiae subsp. Equisimilis between child and dog in an AboriginalAustralian community. Zoonoses Public Health, 61(2), 145-148. https://doi.org/10.1111/zph.12057

Schuchat, A. (1998). Epidemiology of Group B Streptococcal Disease in the United States: Shifting Paradigms. Clinical Epidemiology Reviews, 11(3), 497-513.

Timoney, J. F. (2010). Streptococcus. In C. L. Giles, J. F. Prescott, G. Songer, \& C. O. Thoen (Eds.), Pathogenesis of bacterial infections in animals, 4th ed. lowa, USA: Blackwell Publishing.

Tønnessen, R., Borge, K. S., Nødtvedt, A., \& Indrebø, A. (2012). Canine perinatal mortality: A cohort study of 224 breeds. Theriogenology, 77(9), 1788-1801. DOI: 10.1016/j. Teriogenology. 12.023. https://doi. org/10.1016/j.theriogenology.2011.12.023

Vanrobaeys, M., De Herdt, P., Charlier, G., Ducatelle, R., \& Haesebrouck, F. (1999). Ultrastructure of surface components of Streptococcus gallolytics (S. bovis) strains of differing virulence isolated from pigeons. Microbiology, $145(\mathrm{Pt} \quad 2), 335-342 \mathrm{https} / / /$ doi. org/10.1099/13500872-145-2-335

Vasi, J., Frykberg, L., Carlsson, L. E., Lindberg, M., \& Guss, B. (2000). Mlike proteins of Streptococcus dysgalactiae. Infection Immuntiy, 68(1), 294-302. https://doi.org/10.1128/IAl.68.1.294-302.2000

Vela, A. I., Falsen, E., Simarro, I., Rollan, E., Collins, M. D., Domínguez, L., \& Fernandez-Garayzabal, J. F. (2012). Neonatal mortality in puppies due to bacteremia by Streptococcus dysgalactiae subsp. dysgalactiae. Journal of Clinical Microbiology, 44(2), 666-668.

Verani, J. R., McGee, L., Stephanie, J., \& Schrag, S. J. (2010). Prevention of Perinatal Group B Streptococcal Disease: Revised Guidelines from CDC. Retrieved from http://www.cdc.gov/mmwr/preview/mmwrhtml/ rr5910a1.htm

Veronesi, M. C., Panzani, S., Faustini, M., \& Rota, A. (2009). An Apgar scoring system for routine assessment of newborn puppy viability and short-term survival prognosis. Theriogenology, 72, 401-407. https:// doi.org/10.1016/j

Watts, J. R., Wright, P. J., \& Whithear, K. C. (1996). Uterine, cervical and vaginal microflora of the normal bitch throughout the reproductive cycle. Journal of Small Animal Practice, 37(2), 54-60. https://doi. org/10.1111/j.1748-5827.1996.tb01936.x

Winn, H. N. (2007). Group B Streptococcus infection in pregnancy. Clinics Perinatology, 34, 387-392. https://doi.org/10.1016/j.clp.2007. 03.012

Winn, W., Allen, S., Janda, W., Koneman, A., Procop, G., Schreckenberger, P., \& Woods, G. (2006). Koneman's color atlas and texbook of diagnostic microbiology. Philadelphia, PA: Lippincott Williams \& Wilkin. 6th ed pp. 652-676.

Woo, P. C., Fung, A. M., Lau, S. K., Wong, S. S., \& Yuen, K. Y. (2001). Group $\mathrm{G}$ beta-hemolytic streptococcal bacteremia characterized by $16 \mathrm{~S}$ ribosomal RNA gene sequencing. Journal of Clinical Microbiology, 39(9), 3147-3155. https://doi.org/10.1128/JCM.39.9.3147-3155.2001

How to cite this article: Guerrero AE, Stornelli MA, Jurado SB, et al. Vaginal isolation of beta-haemolytic Streptococcus from bitches with and without neonatal deaths in the litters. Reprod Dom Anim. 2018;00:1-8. https://doi.org/10.1111/rda.13147 